\title{
Egg production and quality of Magelang duck, Mojosari duck, and their reciprocal crosses
}

\author{
Henrik $^{* 1)}$ and Marhayani ${ }^{1)}$ \\ 1) Department of Animal Husbandry, College of Agriculture Science of Mujahidin Tolitoli \\ J1. Dr. Samratulangi No. 51 Tuweley, Tolitoli, Central Sulawesi, Indonesia, 94515
}

Submitted: 29 June 2019, Accepted: 19 October 2020

\begin{abstract}
This experiment was conducted to study the egg production and quality of Magelang, Mojosari duck, and their reciprocal crosses. Forty-eight of twenty weeks old ducks were used for a total of 4 treatments. The treatments were $\mathrm{T} 1=$ Magelang duck; $\mathrm{T} 2=\hat{0}$ Magelang x $q$ Mojosari; T3=Mojosari; and T4= $\hat{\varnothing}$ Mojosari $\mathrm{x} q$ Magelang. This research was design by Completed Randomized Design and replicated by 10 times according to number of female ducks in every treatment. Hen Day Production (HDP) as long as 12 weeks were collected as an egg production variable. Egg weight, albumen weight, yolk weight, shell thickness, and Haugh Unit (HU) as the egg quality variable. Data were analyzed by Analysis of Variance with one-way classification and Honestly Significance Difference. The result showed that were significantly different $(\mathrm{P}<0.01)$ on egg production and quality. The egg production was $60.57,65.29,68.86$, and $61.00 \%$, egg weight was $67.14,59.79,61.80$, and 6.40 $\mathrm{g}$, yolk weight was 25.06, 23.34, 23.23, and $24.46 \mathrm{~g}$, albumen weight was 33.44, 31.41, 31.73, and $33.35 \mathrm{~g}$, shell thickness were $0.50,0.60,0.57$, and 0.53 , HU were 74.24, 74.48, 72.57, and 71.03 respectively for T1, T2, T3, and T4. Egg production of Mojosari duck higher than Magelang duck $(\mathrm{P}<0.01)$ whereas egg quality of Magelang duck higher than Mojosari duck $(\mathrm{P}<0.01)$.
\end{abstract}

Keywords: Egg production; Egg quality; Magelang duck; Mojosari duck; Reciprocal crosses

*Corresponding Author: hendrikaprawi@gmail.com 


\section{INTRODUCTION}

Egg production and quality is an important factor in the egg industry worldwide, include Indonesia. Egg Shell and internal quality are common to use as parameters to determine the quality of the egg. Albumen quality as one of the internal quality is measured by Haugh Unit (HU). Magelang and Mojosari duck have been known as Indonesian local duck with high egg production. Ismoyowati and Purwantini, (2013) reported Hen Day Production (HDP) of Magelang duck reached an average of $70.24 \%$ while Mojosari duck was $74.09 \%$.

Warwick, Astuti, and Hardjosubroto (1995) reported the results of crossing between different strains or species can be produced offspring that are better than their parents. Crossing between two or more different strains of duck can be an effective effort to improve egg production. Prasetyo and Susanti, (2000) were reported crossing between Mojosari and Alabio duck can be increasing egg production until $82.47 \%$. Similar results were also reported by Ketaren and Prasetyo, (2002) that the crossing of Mojosari male duck with Alabio female duck can be reached egg production at $83.31 \%$. However, egg production and quality from Magelang and Mojosari duck that crosses reciprocally, have not been widely reported. Therefore, this study aims to determine the egg production and quality of Magelang duck, Mojosari, and their reciprocal crosses.

\section{MATERIALS AND METHODS}

This experiment was conducted at an experimental farm at the College of Agriculture Science of Mujahidin Tolitoli. Forty-eight of twenty weeks old ducks allotted into 4 groups with 10 replicates (female duck) and 2 male duck (not replicate). The mixed feed was given as much as $170 \mathrm{~g} /$ duck/day that consisting of $40 \%$ corn, $33 \%$ laying concentrate, and $27 \%$ rice bran. Mixed feed was contain $18 \%$ Crude Protein (CP) and $2949 \mathrm{kcal} / \mathrm{kg}$ Metabolism Energy (ME), while drinking water was provided by ad libitum. Every cage consisting of ten female ducks and two male ducks.

The treatments were $\mathrm{T} 1=$ Magelang duck; $\mathrm{T} 2=\hat{\sigma}$ Magelang $\mathrm{x}+$ Mojosari; $\mathrm{T} 3=$ Mojosari; and $\mathrm{T} 4=\hat{\sigma}$ Mojosari $\mathrm{x} q$ Magelang. The parameter was observed were Hen Day Production (HDP) as long as 12 weeks were collected as the egg production parameter. Egg weight, albumen weight, yolk weight, shell thickness, and Haugh Unit (HU) as the egg quality parameter. Hen Day Production measured by the equation below:

$$
\mathrm{HDP}=\frac{\text { number of eggs }}{\text { number of female ducks }} \times 100
$$

Egg weight, albumen weight, and yolk weight measured by analytical weights, while shell thickness measured by micrometer clipper. Haugh Unit measured by Silversides and Villeneuve, (1994) with mathematical model $H U=100 \log (\mathrm{H}+7.57$ $-1.7 \mathrm{~W}^{0,37}$ ) where $\mathrm{H}$; albumen width, and W; egg weight. Data were analyzed using an analysis of variance of one-way classification with mathematical models by Gomez and Gomez (1984).

\section{RESULT AND DISCUSSION}

Egg production and quality of Magelang duck, Mojosari duck, and their reciprocal crosses are presented in Table 1. Based on statistic analyze there were significantly different $(\mathrm{P}<0.05)$ between treatments. Egg production of Mojosari duck (T3) higher than Magelang duck $(\mathrm{P}<0.01)$ but egg quality of Magelang duck higher than Mojosari duck $(\mathrm{P}<0.01)$. When reciprocal crosses implemented (T2 and T4) egg production significantly decreased in Mojosari duck (between T2 and T3) but didn't significantly affect in magelang duck (between $\mathrm{T} 1$ and T4). The higher HU value was $\mathrm{T} 2$, continue with $\mathrm{T} 1, \mathrm{~T} 3$, and $\mathrm{T} 4$. According to this research Ismoyowati \& Purwantini, (2013) reported that egg production of Mojosari duck higher than 
magelang duck (74\% and $70 \%)$ but $\mathrm{HU}$ value of Magelang duck higher than Mojosari duck.

Egg production and quality in this research mainly affected by the maternal effect. The maternal-effect is all of the effects from the parent stock to their offspring (Szwaczkowski et al., 2010) including egg production and egg quality as quantitative traits. Tai et al., (1989) reported that the $h$ value of sire is lower than the $h$ value of the dam. The variation on egg production and quality in this research is the result of the parent's ability to inherit traits where the female duck can play most of the role than the sire of duck. According to Wolc et al., (2012) that reported egg production and egg quality had moderate genetic $h$ value $(0.26-0.74)$. That means the female duck has the ability to inherit the egg production and quality between $26 \%-74 \%$.

There was a significant different between treatment in $\mathrm{HU}$ value $(\mathrm{P}<0.05)$ except between $\mathrm{T} 1$ and $\mathrm{T} 2$. Breed of duck and it's cross breed give significant difference $(\mathrm{P}<0.05)$ on egg weight and albumen weight. This research according to Wolc et al., (2012) reported that egg weight was highly heritable $\left(\mathrm{h}^{2}=0.74\right)$ which means most of the egg weight is influenced by the maternal genetic effect. Further reported the egg weight has a positive genetic correlation with albumen weight (0.32) that explains increasing the albumen weight following by increasing the egg weight.

Table 1. Egg production and quality of Magelang duck, Mojosari duck, and their Reciprocal Crosses*.

\begin{tabular}{clcccc}
\hline No & \multicolumn{1}{c}{ Parameter } & T1 & T2 & T3 & T4 \\
\hline 1 & HDP (\%) & $60,57^{\mathrm{a}}$ & $65,29^{\mathrm{b}}$ & $68,86^{\mathrm{c}}$ & $61,00^{\mathrm{a}}$ \\
2 & Egg weight $(\mathrm{g})$ & $67,14^{\mathrm{b}}$ & $59,79^{\mathrm{a}}$ & $61,80^{\mathrm{a}}$ & $66,40^{\mathrm{b}}$ \\
3 & Yolk weight $(\mathrm{g})$ & $25,06^{\mathrm{b}}$ & $23,34^{\mathrm{a}}$ & $23,23^{\mathrm{a}}$ & $24,46^{\mathrm{ab}}$ \\
4 & Albumen weight $(\mathrm{g})$ & $33,44^{\mathrm{b}}$ & $31,41^{\mathrm{a}}$ & $31,73^{\mathrm{a}}$ & $33,35^{\mathrm{b}}$ \\
5 & Shell Thickness $(\mathrm{mm})$ & $0,50^{\mathrm{a}}$ & $0,60^{\mathrm{c}}$ & $0,57^{\mathrm{b}}$ & $0,53^{\mathrm{a}}$ \\
6 & HU & $74,24^{\mathrm{c}}$ & $74,48^{\mathrm{c}}$ & $72,57^{\mathrm{b}}$ & $71,03^{\mathrm{a}}$ \\
\hline$*$ a,b $\mathrm{P}<0.05$ & & & &
\end{tabular}

Yolk weight of Magelang duck higher than Mojosari duck $(\mathrm{P}<0.01)$ but when reciprocal crosses are implemented didn't significantly effect this trait. That means reciprocal crosses between magelang and mojosari duck can't be increasing or decreasing the yolk weight. According to Wolc et al., (2012) that yolk weigh was highly heritable with $h^{2}$ value 0.34 . Shell thickness as the one external egg quality has significantly different $(\mathrm{P}<0.05)$ in this research. Shell thickness of mojosari duck higher than magelang duck. The highest shell thickness obtained in T2 that mojosari female duck crosses with magelang sire duck.

This research is not in accordance with Ketaren and Prasetyo, (2002) that reported reciprocal crosses can increase egg production caused by differences in the data was used. Ketaren and Prasetyo, (2002) were used the data from offspring as the result of the reciprocal crosses while in this research data were collected from a pure breed that crossing reciprocally. It can explain the reciprocal crosses in this research can't increase the egg production because didn't genetic interaction happened that affecting heterozygosity (h). The change of gene frequencies that occur in DNA had an important role in raising $h$ value (Mulliadi and Arifin, 2010) but if gene interaction is low can't be increasing h value (Henrik, Purwantini, and Ismoyowati, 2018).

\section{CONCLUSIONS}

Egg production and quality between treatments in this research were highly significantly different. Reciprocal crosses in 
this study cannot increase egg production and egg quality because the data is not obtained from the reciprocal crosses offspring. The data were collected from the duck were crossing reciprocally so that only describes the egg production and egg quality at the time.

\section{ACKNOWLEDGMENT}

Sincerest gratitude goes to Directorate General of Higher Education, Ministry of Research, Technology, and Higher Education through Research Centre and Community Service College Agriculture Science of Mujahidin Tolitoli for Funding Competitive Grant and contract No. 113/SP2H/LT/DRPM/2018.

\section{REFERENCES}

Gomez, K.A. \& Gomez, A.A. 1984, Procedure Statistics for Agricultural Research. Diterjemahkan oleh Endang Sjamsudin and Justika S. Bahasjah. 2010. UI-PRESS. Jakarta.

Henrik, Purwantini, D., \& Ismoyowati. (2018). Morphometrics and genetic diversity of Tegal, Magelang, and their crossbred ducks based on Cytochrome $\mathrm{b}$ gene. Journal of the Indonesian Tropical Animal Agriculture, 43(1), 9-18. https://doi. org/10.14710/jitaa.43.1.9-18

Ismoyowati, \& Purwantini, D. (2013). Egg production and quality of local ducks in ducks farming center area. Jurnal Pembangunan Pedesaan. 13(1), 11-16.

Ketaren, P. P., \& Prasetyo, L. H. (2002). Pengaruh pemberian pakan terbatas terhadap produktivitas itik silang Mojosari X Alabio (Ma): 1. masa bertelur fase pertama umur 20-43 minggu. Jurnal Ilmu Ternak Dan Veteriner, 7(2), 76-83.

Mulliadi, D., \& Arifin, J. (2010). Pendugaan keseimbangan populasi dan heterozigositas menggunakan pola protein albumin darah pada populasi domba ekor tipis (Javanese Thin Tailed) di daerah Indramayu (prediction equilibrium of population used blood albumin pattern of Thin Tailed sheep. Jurnal Ilmu Ternak, 10(2), 65-72. https://doi.org/10.24 198/jit.v10i2.419

Prasetyo, L. H., \& Susanti, P. (2000). Persilangan timbal balik antara itik alabio dan mojosari: periode awal bertelur. Jurnal Ilmu Ternak Dan Veteriner, 5(4), 210-214.

Silversides, F. G., \& Villeneuve, P. (1994). Is the haugh unit correction for egg weight valid for eggs stored at room temperature?. Poultry Science, 73(1), 50-55. https://doi.org/10.3382/ps.073 0050

Szwaczkowski, T., Grzech, M., Borowska, A., Wencek, E., \& Wolc, A. (2010). Maternal genetic effects on body weight and breast morphological traits in duck population under selection Zusammenfassung. Archiv Tierzucht, 53, 600-608. https://doi.org/10.5194/ aab-53-600-2010

Tai, C., Rouvier, R., Poivey, J. P., Tai, C., Rouvier, R., \& Genetic, J. P. P. (1989). Genetic parameters of some growth and egg production traits in laying Brown Tsaiya (Anas platyrynchos). Genetics Selection Evolution, 21(3), 377-384. https://10.1186/1297-968621-3-377

Warwick, E.J., Astuti, J.M., \& Hardjosubroto, W. 1995. Pemuliaan Ternak. Edisi 5. Gadjah Mada University Press. Yogyakarta.

Wolc, A., Arango, J., Settar, P., O’Sullivan, N. P., Olori, V. E., White, I. M. S., \& Dekkers, J. C. M. (2012). Genetic parameters of egg defects and egg quality in layer chickens. Poultry Science, 91(6), 1292-1298. https:// doi.org/10.3382/ps.2011-02130 